\title{
Changes of Enzymatic Antioxidants and Minerals Content of Broad Bean (Vicia faba L.) Plants in Response to Chilling Stress and Reacclimation
}

\author{
A. M. Hassan", N. E. Saber and H. M. Abdulaziz \\ Botany \& Microbiology Department, Faculty of Science, Alexandria University, \\ 21511, Alexandria, Egypt and *Faculty of Natural Resources \& Environmental \\ Science, University of Omar El-Mokhtar, Lybia.
}

\begin{abstract}
HILLING stress induced a significant increase of electrolyte leakage (E.L.\%) of broad bean leaves (Vicia faba cv. Nobaria, 1) and that was associated with a significant decrease of normalized concentrations of $\mathrm{K}, \mathrm{Ca}, \mathrm{Mg}, \mathrm{P}, \mathrm{Fe}$ ions and $\mathrm{N}$ (as $\mathrm{NO}_{3}^{-}$) and increase of $\mathrm{Cu}$ and $\mathrm{Zn}$ in leaves and roots. There was a significant accumulation of $\mathrm{H}_{2} \mathrm{O}_{2}$ and malondialdehyde (MDA) contents accompanied with a significant increase of enzymatic antioxidants (SOD, CAT, APx, GR and PPO) activities. During the $6 \mathrm{~h}$ reacclimation period, the CAT, APx, GR and PPO activities were significantly increased compared to those of chill-stressed plants, whereas SOD significantly decreased. There are several polypeptides bands were markedly appeared in leaves and roots during the exposure to low temperature and $6 \mathrm{~h}$ reacclimation period. The results revealed that chilling temperature had an inhibitory effect on the plasma membrane integrity due to enhancement of ROS generation and that might associate with an increase of enzymatic antioxidants activities and appearance of several stress proteins during chilling and reacclimation periods.
\end{abstract}

Keywords: Chilling stress, $\mathrm{H}_{2} \mathrm{O}_{2}$, MDA, Antioxidant enzymes, Protein.

\section{Introduction}

Heat stress (high or low temperature) is a major environmental factor limiting the growth and adaptation of plants. Cold temperature stress $(0-$ $10^{\circ} \mathrm{C}$ ) has a broad spectrum effects on cellular components including plasma membranes, chloroplasts and mitochondria as well as physiological and biochemical processes of plants (Mostafa \& Hassan, 2006 and Yin et al., 2009). Moreover, low temperature has an inhibitory effect on uptake of mineral elements such as $\mathrm{P}$, $\mathrm{K}, \mathrm{Ca}, \mathrm{Mg}, \mathrm{Fe}, \mathrm{Zn}$ and $\mathrm{B}$ and their allocation between different plant organs, and finally depress the growth (Taspinar et al., 2009 and Nxawe et al., 2010). Ercoli et al. (2004) reported that a marked decrease of relative growth rate and $\mathrm{N}$-uptake of chilling-exposed sorghum plant. In addition, El-Mohtasem (2008) concluded that the net $\mathrm{NO}_{3}^{-}$uptake by both barley and maize plants was greatly increased by increasing temperature between $15^{\circ} \mathrm{C}$ to $25^{\circ} \mathrm{C}$. On the other hand, Jan et al. (2015) reported that no significant change in the concentration of $\mathrm{K}, \mathrm{Na}$ and $\mathrm{Ca}$ ions in rice plants under different chilling temperatures.

Many authors (Suzuki \& Mittler, 2006; Mostafa \& Sorour, 2014 and Jan et al., 2015) have been reported that heat stress resulted in generation of reactive oxygen species (ROS) which causing rapid cellular damage to plasma membranes, proteins, DNA and hence suppressing plant growth and development. Under heat stress, plants contain numerous enzymatic ROSscavengers antioxidants, including superoxide dismutase (SOD), catalase (CAT), peroxidase (POx), ascorbate peroxidase (APx), glutathione peroxidase (GPx) and glutathione reductase (GR) as well as non enzymatic antioxidants such as ascorbate, glutathione and phenolics (Kang \&

"Corresponding author email: atiathasan@yahoo.com 
Saltveit, 2002; Gill \& Tuteja, 2010 and Cui \& Zhou, 2013).

It has been reported that chilling stress enhanced SOD activity in several plants including cucumber (Kang \& Saltveit, 2002), wheat (Hajiboland \& Habibi, 2011) and citrus fruit (Mohammadian et al., 2012). Cui et al. (2013) reported that CAT activity significantly increased during chilling stress, while Ping et al. (2012) reported a decrease of CAT activity in rubber tree clones seedlings in response to chilling stress. APx is the first enzyme of the ascorbateglutathione cycle, which catalyzes the reduction of $\mathrm{H}_{2} \mathrm{O}_{2}$ to water and has high specificity and affinity for ascorbate as reductant (Asada, 1999). Mohammadian et al. (2012) observed a maximum level of APx enzyme activity in unripe and ripened Citrus unshiu fruits in response to chilling stress, whereas, Cui \& Zhou (2013) reported a different change trends of APx activity with different variety of Nicotiana tabacum seedlings under chilling stress. GR plays an important role in the control of endogenous $\mathrm{H}_{2} \mathrm{O}_{2}$ content through an oxido-reduction cycle involving glutathione and ascorbate (Edwards et al., 1991). Kang \& Saltveit (2001) reported that GR activity was increased by the injurious chilling stress in cucumber seedlings. Moreover, Galli et al. (2009) concluded that increasing ROS generation in chilled pawpaw fruit was accompanied with an increase of polyphenol oxidase (PPO) activity. Weisany et al. (2012) suggested that PPO is an oxidoreductase that catalyzed the oxidation of phenolics, usually by generated oxygen radicals, to quinoues and also eliminated the toxic effect of reacumulated phenolics. In contrast, Wongsheree et al. (2009) stated that PPO activity and total phenolic content in young and mature leaves of lemon plant were greatly decreased at $4^{\circ} \mathrm{C}$.

Vierling (1991) reported that, there was an expression of specific proteins (heat shock proteins, HSPs) are known as adaptive mechanism to heat stress, these HSPs have molecular masses ranged between $10 \mathrm{KDa}-100 \mathrm{KDa}$ with special functions as introducing in folding cellular proteins and protecting the functional sites of several enzymes. A number of other proteins have been identified such as protective proteins, cold-regulated protein, cold-acclimated and antifreezing proteins which play important roles against heat stress (Shinozaki et al., 2003 and Badowiec et al., 2013).
The aim of this study was to throw a beam of light on the effect of non-lethal low temperature stress on some minerals content and development of enzymatic antioxidants as a defense mechanism in leaves and roots of broad bean plants during the exposure and reacclimation periods.

\section{Materials and Methods}

Broad bean seeds (Vicia faba L cv. Nobaria, 1) were obtained from the Agricultural Research Center, Giza, Egypt, surface sterilized by soaking for two minutes in $4 \%(\mathrm{v} / \mathrm{v})$ sodium hypochlorite, then washed several times with distilled water, soaked in distilled water for $24 \mathrm{~h}$ with aeration, and then transferred to plastic pots $(15 \mathrm{~cm}$ diameter) filled with acid-washed quartz sand. The pots were kept under natural environmental conditions of light and darkness (temperature varied from $20 \pm 3^{\circ} \mathrm{C}$ during the day and $15 \pm 3{ }^{\circ} \mathrm{C}$ during night) and irrigated with distilled water every twoday interval. After fifteen days (from sowing) homogenous seedlings were taken carefully from the pots, washed from adhering sand with tap water then with distilled water and finally blotted gently with tissue paper. Five seedlings were transferred to $250-\mathrm{ml}$, wide mouth bottles containing $200 \mathrm{ml}$ of hydroponic solution (1/10 strength Hoagland solution). The bottles were kept in a temperaturecontrolled growth chamber at $10^{\circ} \mathrm{C}$ in the dark. Another bottles left in natural conditions as a control. At the desired experimental period $(3,6$, 12 and $24 \mathrm{~h}$ ), the treated plants were divided into two groups, plants of the first group were left as stressed plants and the other group was subjected to natural conditions for $6 \mathrm{~h}$ (reacclimation). Replicate seedlings from the two groups were taken, washed with distilled water, dried gently with tissue paper and then divided into shoots and roots. Enough samples were immediately stored at $-80^{\circ} \mathrm{C}$ for future enzyme assay and protein electrophoresis. Other samples (as fresh or dried at $60{ }^{\circ} \mathrm{C}$ in an oven to constant weight) were stored for chemical analyses.

\section{Estimation of electrolyte leakage (\%EL)}

Electrolyte leakage was determined according to Dionisio-Sese \& Tobita (1998). The electrolyte leakage $(\% \mathrm{EL})$ was expressed following the formula:

$$
\% \mathrm{EL}=\mathrm{EC} 1 / \mathrm{EC} 2 \times 100
$$

where, EC1: the initial electrical conductivity and EC2: final electrical conductivity after the samples autoclaved at $120^{\circ} \mathrm{C}$ for $20 \mathrm{~min}$. 


\section{Estimation of nutrient elements}

This was done according to the method of Taspinar et al. (2009). The roots and leaves of chill-treated and untreated broad bean seedlings were dried at $60^{\circ} \mathrm{C}$ to a constant weight, then ground in a ceramic mortar with liquid nitrogen to make the sample as homogenous slurry. The samples were transferred to wavelength dispersive X-ray scanning microscope (WSXRSM, Jeol, JSM5300) attached with SEM Oxford unit. This instrument was controlled by a software computer for determination of $\mathrm{K}, \mathrm{Ca}, \mathrm{Mg}, \mathrm{P}$, $\mathrm{Fe}, \mathrm{Cu}$ and $\mathrm{Zn}$ contents. The measurements were calculated as a percent to each other.

\section{Estimation of nitrate}

Nitrate was estimated using phenol disulphonic acid reagent (Johnson \& Ulrich, 1950). The colour developed was measured at $420 \mathrm{~nm}$ using spectrophotometer (JENWAY, 6305, UK) with reference to known concentrations of nitrate as $\mathrm{KNO}_{3}$.

\section{Estimation of hydrogen peroxide $\left(\mathrm{H}_{2} \mathrm{O}_{2}\right)$}

Hydrogen peroxide content was determined accordingto Velikova et al.(2000). The reaction mixture contained $0.5 \mathrm{ml}$ plant extract, $0.5 \mathrm{ml}$ of $10 \mathrm{mM}$ potassium phosphate buffer $(\mathrm{pH}, 7$ ) and $0.1 \mathrm{ml} 1 \mathrm{M} \mathrm{KI}$. The absorbance of the mixture was measured at $390 \mathrm{~nm}$. The content of $\mathrm{H}_{2} \mathrm{O}_{2}$ was calculated by comparison with a standard calibration curve using different concentration of $\mathrm{H}_{2} \mathrm{O}_{2}$.

\section{Estimation of lipid peroxidation}

Lipid peroxidation was measured as the amount of malondialdehyde (MDA) produced by the thiobarbituric acid (TBA) reaction, as described by Zhang et al. (2007).

\section{Assay of antioxidant enzymes \\ Enzymes extraction}

Antioxidant enzymes were extracted according to the method of Azevedo Neto et al. (2006). Fresh samples $(0.20 \mathrm{~g})$ were homogenized in a mortar and pestle with 4 $\mathrm{ml}$ of ice-cold extraction buffer (100 mM potassium phosphate buffer [pH 7] containing $0.1 \mathrm{mM}$ EDTA). Each homogenate was filtered through muslin cloth and centrifuged at 16,000 $\mathrm{g}$ for $15 \mathrm{~min}$. The supernatant fraction was used as crude extract for enzyme activity. All operations were carried out at $4^{\circ} \mathrm{C}$.
Superoxide dismutase (SOD, EC 1.15.1.1) assay

Superoxide dismutase activity was determined as described by Giannopolitis \& Ries (1977) via measuring its ability to inhibit the photochemical reduction of nitroblue tetrazolium chloride (NBT). One unit of SOD activity (U) was defined as the amount of enzyme required to cause $50 \%$ inhibition of the NBT photoreduction rate.

Catalase (CAT, EC 1.11.1.6) assay

Catalase activity was measured according to the method described by Azevedo Neto et al. (2006). The decrease of $\mathrm{H}_{2} \mathrm{O}_{2}$ was monitored at $240 \mathrm{~nm}$ and quantified by its molar extinction coefficient $\left(36 \mathrm{M}^{-1} \mathrm{~cm}^{-1}\right)$.

Ascorbate peroxidase (APX, EC 1.11.1.11) assay

Ascorbate peroxidase activity was assayed according to Nakano \& Asada (1981) and the enzyme activity was quantified using the molar extinction coefficient for ascrorbate $\left(2.8 \mathrm{mM}^{-1}\right.$ $\mathrm{cm}^{-1}$ ) and the result expressed in $\mu \mathrm{mol} \mathrm{H}_{2} \mathrm{O}_{2}$ $\mathrm{g}^{-1}$ f.m. min. ${ }^{-1}$, taking into consideration that 2 mol ascorbate are required for reduction of 1 mol $\mathrm{H}_{2} \mathrm{O}_{2}$ (Mckersie \& Leshem, 1994).

Glutathione reductase (GR, EC 1.6.4.2) assay

Glutathione reductase activity was assayed according to Foyer \& Halliwell (1976) with minor modifications as described by Azevedo Neto et al. (2006) and the oxidation rate was monitored at $340 \mathrm{~nm}$ for $1 \mathrm{~min}$. The enzyme activity was determined using the molar extinction coefficient for NADPH $\left(6.2 \mathrm{mM}^{-1}\right.$ $\left.\mathrm{cm}^{-1}\right)$.

Polyphenol oxidase (PPO, EC 1.10.3.1) assay

The polyphenol oxidase activity (PPO) was assayed as the method described by Kumar \& Khan (1982). PPO activity was expressed in $\mathrm{U} \mathrm{min}^{-1} \mathrm{~g}^{-1}$ f.m. One unit (U) is defined as the amount of purpurogallin formed, which raised the absorbance by 0.1 per minute under the assay condition.

\section{Protein electrophoresis \\ SDS Polyacrylamide gel electrophoresis}

(SDS-PAGE) was performed to distinguish fragments of total soluble protein for treated and untreated leaves and rootsof Vicia faba plants according to the methods of Laemmli (1970). 


\section{Statistical analysis}

Statistical analysis was done using Statistical Package for Social Sciences (SPSS/version 20) software. All treatments were replicated three times and results are given as mean. Arthematic mean, standard deviation, to compare between two groups student t-test was used, while for more than two groups ANOVA test was used. The level of significant was $\leq 0.05$.

\section{Results}

Changes in electrolyte leakage (E.L.\%)

Increasing the duration of exposure to chilling temperature resulted in a significant increase of E.L.\%. At $6 \mathrm{~h}$ and $24 \mathrm{~h}$ of chilling stress, the E.L. values were 1.7- and 2.8-fold of control, respectively (Table 1). During $6 \mathrm{~h}$ of reacclimation period, the E.L.\% values were markedly declined compared to stressed plants, but the attained values still higher than those of control plants.

TABLE 1. Changes in electrolyte leakage (E.L.\%) of leaves of 15 day-old broad bean seedlings in response to chilling stress (Chilled) and $6 \mathrm{~h}$ reacclimation period (Reac).

\begin{tabular}{lcccc}
\hline Treatments & $\mathbf{3}$ & $\mathbf{6}$ & $\mathbf{1 2}$ & $\mathbf{2 4}$ \\
\hline Control & 12.9 & 13.2 & 13.5 & 13.3 \\
Chilled & $15.0^{*}$ & $22.3^{*}$ & $29.7^{*}$ & $36.9^{*}$ \\
P & 0.031 & 0.001 & 0.001 & 0.001 \\
6h Reac & & & & \\
Control & 13.5 & 13.3 & 13.3 & 13.2 \\
Chilled & 13.4 & 16.7 & 18.3 & $23.4^{*}$ \\
P & 0.698 & 0.101 & 0.069 & 0.003 \\
\hline
\end{tabular}

Mean values of treated plants were compared to that of the controls. Significance levels represented by $\mathrm{P} * 0.05$

Changes in nutrient elements content

Long period of exposure (12-24 h) of $15 \mathrm{~d}$-old broad bean plants to non-lethal chilling temperature mainly resulted in a significant decrease in normalized concentration of selected macronutrients ( $\mathrm{K}, \mathrm{Ca}, \mathrm{Mg}, \mathrm{P}$ and $\mathrm{Fe}$ ) content in leaves of broad bean plants, whereas a significantly decrease of $\mathrm{K}$ and $\mathrm{Ca}$ was detected in roots in response to the duration of exposure (Table 2). Conversely to this decline of the selected macronutrient content, $\mathrm{Cu}$ and $\mathrm{Zn}$ contents were significantly increased. At $6 \mathrm{~h}$ post-stress period (reacclimation period), generally, there was a marked increase of all tested normalized concentration of macronutrients accumulation in leaves and roots of chilled broad bean plants. In contrast, there was a great decrease of $\mathrm{Cu}$ and $\mathrm{Zn}$ contents. It is noteworthy that the normalized macronutrients accumulation in all previously chilled plants except those exposed for $24 \mathrm{~h}$, increased reaching to nearly the control values after $6 \mathrm{~h}$ reacclimation period.

\section{Changes in nitrate content}

Nitrate content in leaves and roots of control (untreated) plants was gradually increased with increasing experimental period. At short time of exposure to chilling stress (3-6 h), there was an increase of $\mathrm{NO}_{3}$ - content in the leaves of broad bean plants then markedly declined with increasing of exposure time; the attained values were lower than those in control. On the other hand, nitrate content was significantly increased in chilled roots with increasing exposure time up to $12 \mathrm{~h}$ compared to control (Table 3 ). These results could reveal the inhibitory effect of chilling temperature on $\mathrm{NO}_{3}^{-}$ transport within plant organs.

During $6 \mathrm{~h}$ reacclimation period, $\mathrm{NO}_{3}^{-}$content in leaves was markedly increased compared to stressed plants, but the attained values were significantly lower than those of unstressed plants. Conversely, the $\mathrm{NO}_{3}^{-}$contentin roots was markedly decreased compared to stressed plants; the values reached to those of control plants.

Changes in hydrogen peroxide and malondialdehyde contents

It is clearly seen that chilling temperature at $10^{\circ} \mathrm{C}$ resulted in a significant accumulation of $\mathrm{H}_{2} \mathrm{O}_{2}$ and MDA contents in leaves and roots of broad bean plant with increasing the duration period of exposure (Table 4). On the other hand, there was a significant decrease of both $\mathrm{H}_{2} \mathrm{O}_{2}$ and MDA contents in leaves and roots during $6 \mathrm{~h}$ reacclimation period compared to chillingstressed plant, but the attained values were, however, significantly higher than those of control. These observations might indicate an improvement of the plasma membranes integrity and scavenging the generated ROS during reacclimation period. 


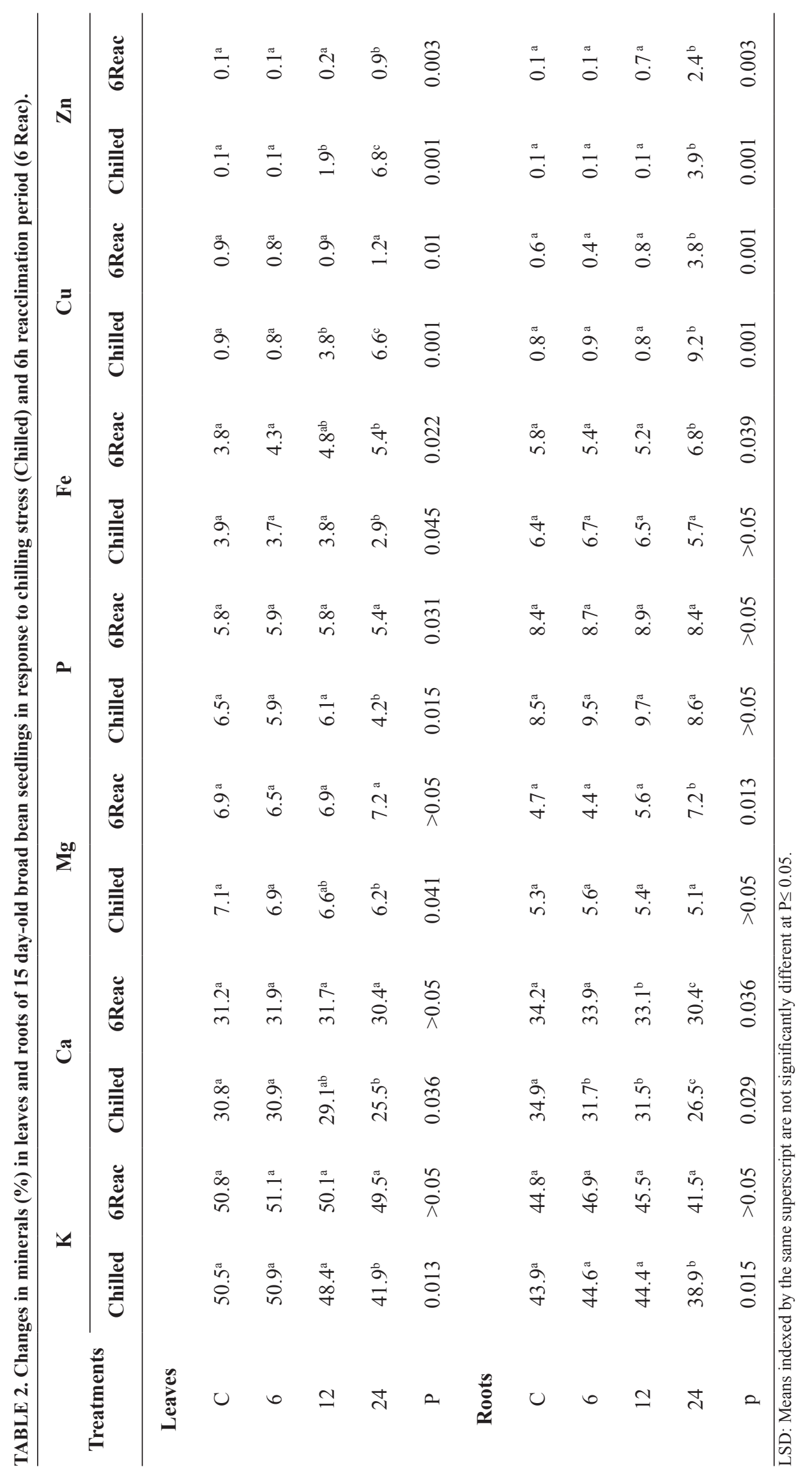

Egypt. J. Bot., Vol. 57, No.3 (2017) 
TABLE 3. Changes in nitrate content in leaves and roots of 15 day-old broad bean seedlings in response to chilling stress (Chilled) and $6 \mathrm{~h}$ reacclimation period (6 Reac).

\begin{tabular}{|c|c|c|c|c|c|c|c|c|}
\hline \multirow[t]{3}{*}{ Treatments } & \multicolumn{4}{|c|}{$\begin{array}{l}\text { Leaves } \\
\text { Time, h }\end{array}$} & \multicolumn{4}{|c|}{$\begin{array}{c}\text { Roots } \\
\text { Time, h }\end{array}$} \\
\hline & 3 & 6 & 12 & 24 & 3 & 6 & 12 & 24 \\
\hline & \multicolumn{8}{|c|}{$\mathrm{mg} \mathrm{NO}_{3}^{-} \mathrm{g}^{-1}$ d.m. } \\
\hline Control & 7.7 & 9.66 & 11.11 & 12.53 & 1.66 & 2.36 & 2.76 & 2.12 \\
\hline Chilled & $3.06^{*}$ & $3.12 *$ & $1.93 *$ & $0.99 *$ & $2.27 *$ & $4.69^{*}$ & $4.71^{*}$ & 2.59 \\
\hline $\mathrm{P}$ & 0.01 & 0.001 & 0.001 & 0.001 & 0.033 & 0.01 & 0.01 & $>0.05$ \\
\hline \multicolumn{9}{|l|}{6 Reac } \\
\hline Control & 11.01 & 17.50 & 11.66 & 12.75 & 1.78 & 1.79 & 2.30 & 2.38 \\
\hline Chilled & $5.42 *$ & $6.11^{*}$ & $4.93 *$ & $2.88^{*}$ & 1.43 & 2.38 & 2.53 & 2.35 \\
\hline $\mathrm{P}$ & 0.001 & 0.001 & 0.001 & 0.001 & $>0.05$ & $>0.05$ & $>0.05$ & $>0.05$ \\
\hline
\end{tabular}

Mean values of treated plants were compared to that of the controls.

Significance levels represented by $\mathrm{P}^{*} \leq 0.05$

TABLE 4. Changes of hydrogen peroxide $\left(\mathrm{H}_{2} \mathrm{O}_{2}\right)$ and malondialdehyde (MDA) contents in leaves and roots of 15 day- old broad bean seedlings in response to chilling stress (Chilled) and $6 \mathrm{~h}$ reacclimation (6Reac).

\begin{tabular}{|c|c|c|c|c|c|c|c|c|}
\hline \multirow{4}{*}{ Treatments } & \multirow{2}{*}{\multicolumn{4}{|c|}{$\begin{array}{l}\text { Leaves } \\
\text { Time, } h\end{array}$}} & \multirow{2}{*}{\multicolumn{4}{|c|}{$\begin{array}{c}\text { Roots } \\
\text { Time, h }\end{array}$}} \\
\hline & & & & & & & & \\
\hline & 3 & 6 & 12 & 24 & 3 & 6 & 12 & 24 \\
\hline & \multicolumn{8}{|c|}{$\mu \mathrm{mol} \mathrm{H}_{2} \mathrm{O}_{2} \mathrm{~g}^{-1} \mathbf{f} . \mathrm{m}$} \\
\hline Control & 14.61 & 14.81 & 16.93 & 20.20 & 9.30 & 9.38 & 9.33 & 9.51 \\
\hline Chilled & $42.92 *$ & $50.99^{*}$ & $55.00 *$ & $67.95^{*}$ & $23.60^{*}$ & $31.89^{*}$ & $38.69 *$ & $45.29 *$ \\
\hline P & 0.001 & 0.001 & 0.001 & 0.001 & 0.001 & 0.001 & 0.001 & 0.001 \\
\hline \multicolumn{9}{|l|}{ 6h Reac } \\
\hline Control & 15.11 & 15.20 & 16.74 & 19.29 & 9.52 & 9.91 & 11.22 & 10.98 \\
\hline Chilled & 15.34 & $20.51 *$ & $23.66^{*}$ & $39.90 *$ & 10.11 & $16.70 *$ & $19.98 *$ & $29.97 *$ \\
\hline $\mathrm{P}$ & $>0.05$ & 0.002 & 0.013 & 0.001 & $>0.05$ & 0.01 & 0.01 & 0.001 \\
\hline & \multicolumn{8}{|c|}{ 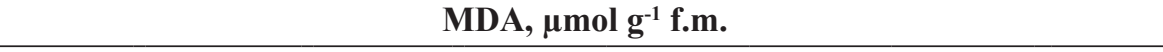 } \\
\hline Control & 4.37 & 4.55 & 4.61 & 4.67 & 3.77 & 3.71 & 3.81 & 3.89 \\
\hline Chilled & 5.64 & $9.90 *$ & $18.72 *$ & $30.39^{*}$ & $5.49^{*}$ & $8.14^{*}$ & $13.03^{*}$ & $23.32 *$ \\
\hline $\mathrm{P}$ & $>0.05$ & 0.001 & 0.001 & 0.001 & 0.033 & 0.01 & 0.001 & 0.001 \\
\hline $\begin{array}{l}\text { 6h Reac } \\
\text { Control }\end{array}$ & 4.52 & 4.56 & 4.70 & 4.75 & 3.88 & 3.08 & 3.95 & 3.99 \\
\hline Chilled & 4.90 & 4.73 & $10.69 *$ & $20.57 *$ & $3.76^{*}$ & $4.27^{*}$ & $9.07 *$ & $16.95^{*}$ \\
\hline $\mathrm{P}$ & $>0.05$ & $>0.05$ & 0.001 & 0.001 & 0.001 & 0.047 & 0.001 & 0.001 \\
\hline
\end{tabular}

Mean values of treated plants were compared to that of the controls. Significance levels represented by $P^{*} \leq 0.05$.

\section{Changes in SOD activity}

Generally, increasing duration period of chilling stress resulted in a significant increase of SOD activity in leaves and roots of broad bean plant compared to unstressed control (Table 5). It is shown that during the reacclimation period, the SOD activity in plants was significantly decreased comparing to those exposed to chilling treatment. At the end of $6 \mathrm{~h}$ reacclimation period, the decrease of SOD activity in leaves and roots of previously exposed to $24 \mathrm{~h}$ chilling temperature was $47 \%$ and $51 \%$, respectively compared to chilling-stressed plants.

\section{Changes in CAT activity}

Catalase activity in leaves and roots of 15d-old broad bean plants was significantly increased in response to duration period of chilling exposure compared to control (Table 5). Dissimilar to SOD, there was a significant increase of CAT activity in leaves and roots during the $6 \mathrm{~h}$ reacclimation period compared to those of previously chilled plants. At 6 $\mathrm{h}$ reacclimation period, the increase of CAT activity in 24 h-chilled leaves and root was $12 \%$ and $14 \%$, respectively, compared to those of chilled plants. 
TABLE 5. Changes in the superoxide dismutase (SOD), catalase ( CAT), ascorbate peroxidase (APx), polyphenol oxidase (PPO), glutathione reductase (GR) activities of leaves and roots of 15 day-old broad bean seedlings in response to chilling stress (Chilled) and $6 \mathrm{~h}$ reacclimation period (6 Reac).

\begin{tabular}{|c|c|c|c|c|c|c|c|c|}
\hline \multirow[t]{2}{*}{ Treatments } & \multicolumn{4}{|c|}{$\begin{array}{c}\text { Leaves } \\
\text { Time (h) }\end{array}$} & \multicolumn{4}{|c|}{$\begin{array}{c}\text { Roots } \\
\text { Time (h) }\end{array}$} \\
\hline & 3 & 6 & 12 & 24 & 3 & 6 & 12 & 24 \\
\hline & \multicolumn{8}{|c|}{ SOD activity, $\mathrm{U} \mathrm{g}^{-1}$ f.m } \\
\hline Control & 9.22 & 9.21 & 9.53 & 9.62 & 5.04 & 5.17 & 5.93 & 6.14 \\
\hline Chilled & 10.66 & $29.27 *$ & $44.59 *$ & $77.71 *$ & 6.89 & $13.72 *$ & $28.94 *$ & $45.07 *$ \\
\hline $\mathrm{P}$ & $>0.05$ & 0.001 & 0.001 & 0.001 & $>0.05$ & 0.001 & 0.001 & 0.001 \\
\hline $\begin{array}{l}\text { 6h Reac } \\
\text { Control }\end{array}$ & 9.24 & 9.30 & 9.58 & 9.66 & 5.18 & 5.24 & 5.99 & 6.28 \\
\hline Chilled & 9.46 & $14.20^{*}$ & $23.62 *$ & $41.08^{*}$ & 5.67 & $7.17 *$ & $11.66^{*}$ & $22.13 *$ \\
\hline \multirow[t]{2}{*}{$\mathrm{P}$} & $>0.05$ & 0.022 & 0.001 & 0.001 & $>0.05$ & 0.036 & 0.001 & 0.001 \\
\hline & \multicolumn{8}{|c|}{ CAT activity, $\mu \mathrm{mol} \mathrm{H}_{2} \mathrm{O}_{2} \mathrm{~g}^{-1}$ f.m } \\
\hline Control & 18.85 & 19.79 & 19.05 & 19.46 & 16.30 & 16.38 & 16.95 & 17.13 \\
\hline Chilled & $24.72 *$ & $31.29 *$ & $40.03 *$ & $43.89 *$ & 17.25 & $23.94 *$ & $33.18 *$ & $33.87^{*}$ \\
\hline $\mathrm{P}$ & 0.033 & 0.01 & 0.001 & 0.001 & $>0.05$ & 0.001 & 0.001 & 0.001 \\
\hline $\begin{array}{l}\text { 6h Reac } \\
\text { Control }\end{array}$ & 19.11 & 19.47 & 19.50 & 19.56 & 16.28 & 16.44 & 16.97 & 17.25 \\
\hline Chilled & $25.22 *$ & $37.01 *$ & $49.59 *$ & $49.26^{*}$ & 19.25 & $27.94 *$ & $38.09 *$ & $38.67 *$ \\
\hline \multirow[t]{2}{*}{$\mathrm{P}$} & 0.021 & 0.001 & 0.001 & 0.001 & $>0.05$ & 0.001 & 0.001 & 0.001 \\
\hline & \multicolumn{8}{|c|}{ APx activity, $\mu \mathrm{mol} \mathrm{H}_{2} \mathrm{O}_{2} \mathrm{~g}^{-1}$ f.m } \\
\hline Control & 7.49 & 7.79 & 7.93 & 8.44 & 4.08 & 4.31 & 4.29 & 5.37 \\
\hline Chilled & 8.42 & $11.87^{*}$ & $19.02 *$ & $24.59 *$ & $6.87 *$ & $9.43 *$ & $14.99 *$ & $22.18^{*}$ \\
\hline $\mathrm{P}$ & $>0.05$ & 0.011 & 0.001 & 0.001 & 0.013 & 0.006 & 0.001 & 0.001 \\
\hline $\begin{array}{l}\text { 6h Reac } \\
\text { Control }\end{array}$ & 8.08 & 8.53 & 8.67 & 9.07 & 4.30 & 4.38 & 4.89 & 5.15 \\
\hline Chilled & 8.71 & $13.91 *$ & $23.56^{*}$ & $35.68 *$ & $7.16^{*}$ & $11.93 *$ & $16.80^{*}$ & $26.79 *$ \\
\hline \multirow[t]{2}{*}{$\mathrm{P}$} & $>0.05$ & 0.017 & 0.001 & 0.001 & 0.022 & 0.001 & 0.001 & 0.001 \\
\hline & \multicolumn{8}{|c|}{ PPO activity, $\mathrm{U} \mathrm{min}^{-1} \mathrm{~g}^{-1}$ f.m } \\
\hline Control & 0.332 & 0.352 & 0.368 & 0.371 & 0.422 & 0.415 & 0.420 & 0.427 \\
\hline Chilled & $0.470 *$ & $0.684^{*}$ & $0.788^{*}$ & $0.832 *$ & 0.592 & $0.815^{*}$ & $0.948^{*}$ & $1.063 *$ \\
\hline $\mathrm{P}$ & 0.013 & 0.011 & 0.001 & 0.001 & $>0.05$ & 0.001 & 0.001 & 0.001 \\
\hline $\begin{array}{l}\text { 6h Reac } \\
\text { Control }\end{array}$ & 0.377 & 0.383 & 0.388 & 0.424 & 0.424 & 0.491 & 0.552 & 0.56 \\
\hline Chilled & $0.640 *$ & $0.834^{*}$ & $1.259^{*}$ & $1.532 *$ & $0.702 *$ & $1.331^{*}$ & $1.854^{*}$ & $2.397 *$ \\
\hline \multirow[t]{2}{*}{$\mathrm{P}$} & 0.021 & 0.002 & 0.001 & 0.001 & 0.023 & 0.011 & 0.001 & 0.001 \\
\hline & \multicolumn{8}{|c|}{ GR activity, $\mu$ mol NADPH $\mathrm{g}^{-1}$ f.m.min ${ }^{-1}$} \\
\hline Control & 19.96 & 19.76 & 20.06 & 20.75 & 12.14 & 12.22 & 12.29 & 12.37 \\
\hline Chilled & $22.35 *$ & $24.92 *$ & $28.50 *$ & $34.64 *$ & 14.84 & 16.32 & $23.95^{*}$ & $25.80 *$ \\
\hline $\mathrm{P}$ & 0.016 & 0.01 & 0.01 & 0.001 & $>0.05$ & $>0.05$ & 0.001 & 0.001 \\
\hline $\begin{array}{l}\text { 6h Reac } \\
\text { Control }\end{array}$ & 21.06 & 21.32 & 22.15 & 22.28 & 12.40 & 12.68 & 12.77 & 12.79 \\
\hline Chilled & $27.93 *$ & $36.30 *$ & $46.83 *$ & $52.87^{*}$ & 19.13 & $31.96^{*}$ & $36.60 *$ & $44.15^{*}$ \\
\hline $\mathrm{P}$ & 0.021 & 0.011 & 0.001 & 0.001 & $>0.05$ & 0.001 & 0.001 & 0.001 \\
\hline
\end{tabular}

Mean values of treated plants were compared to that of the controls. Significance levels represented by $P^{*} \leq 0.05$. 


\section{Changes in APx activity}

Similar to CAT, it is clearly demonstrated that APx activity was significantly increased in chilled-stressed plants with increasing the duration of exposure to chilling temperature and during $6 \mathrm{~h}$ reacclimation period compared to untreated plant (Table5).

\section{Changes in PPO activity}

Similar to the trends of both CAT and APx, polyphenol oxidase (PPO) activity in leaves and roots of broad bean plants was significantly increased with increasing the duration of exposure to chilling stress and, also, during reacclimation period (Table 5). These observations might indicate the generation of a defense mechanism during chilling and reacclimation periods for quenching the oxidative stress caused by generated ROS.

\section{Changes in GR activity}

Results in Table 5 show a significant enhancement of GR activity in leaves and roots of broad bean

\section{Leaves}

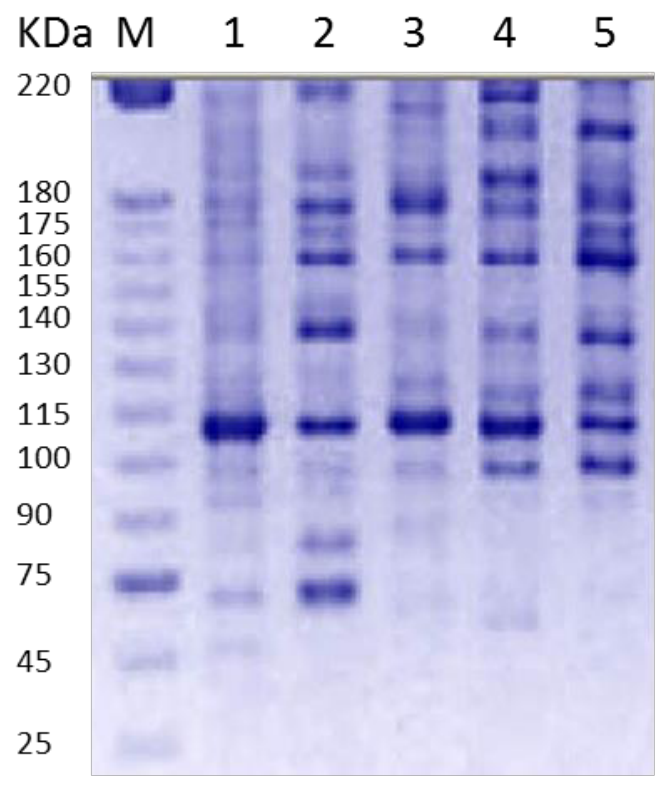

plants grown under non-lethal temperature. This induction was significantly increased during the $6 \mathrm{~h}$ reacclimation period.

\section{Changes in protein profile}

Exposure of broad bean plants to chilling temperature resulted in notable differences in both migration and intensity of isolated polypeptides in leaves and roots (Plate 1). There were 14 protein bands with molecular mass (M.M) ranged between $214 \mathrm{KDa}$ to $25 \mathrm{KDa}$ in the leaves of control plants (Lane 1). Under 6 and $24 \mathrm{~h}$ duration periods of chilling stress and $6 \mathrm{~h}$ reacclimation period, polypeptide bands with M.M. of $104 \mathrm{KDa}$ and $71 \mathrm{KDa}$ were completely disappeared in the stressed leaves (Table 6a). On the other hand, two novel heat shock proteins (HSPs) with M.M. of $75 \mathrm{KDa}$ and $69 \mathrm{KDa}$ were appeared after 6 $\mathrm{h}$ of chilling stress (Lane 2) and $6 \mathrm{~h}$ reacclimation period (Lane 3).

\section{Roots}

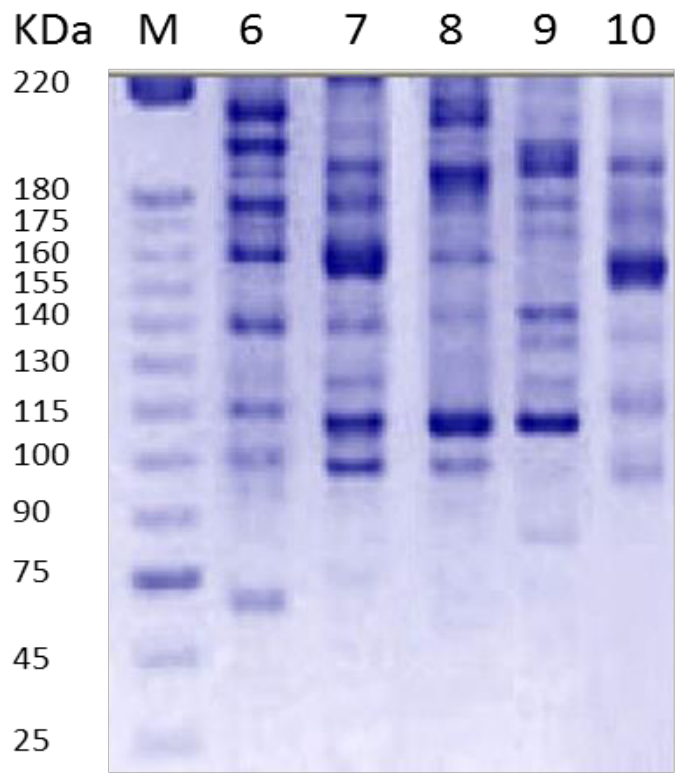

Plate 1. SDS-PAGE electrophoretic profile of proteins of of 15 day-old broad bean seedlings under 6 and $24 \mathrm{~h}$ chillstressed and $6 \mathrm{~h}$ reacclimation $(6 \mathrm{~h}$ Reac) periods in leaves and roots. Lanes 1,6 (control); lanes 2, 7 (6 h stressed); lanes 3, 8 (6 h chilled-6 h Reac) lanes 4, 9 (24 h stressed); lanes 5,10 (24 h-stressed-6 h Reac).

At 24 h-chilling stress leaves, four polypeptide HSPs with M.M. of 175, 95, 58 and $30 \mathrm{KDa}$ were markedly appeared (Lane 4) with completely disappeared of 168, 156, 127 and 84 KDa bands. During $6 \mathrm{~h}$ reacclimation period of 24 h-chilling treated plants two HSPs of 156 and $127 \mathrm{KDa}$ polypeptide bands were appeared with disappearance of 58 and $30 \mathrm{KDa}$ polypeptides (Lane 5). SDS-PAGE (Plate 1) show also a great variation of molecular masses of soluble protein in chilled-stressed and during reacclimation period of broad bean roots compared to untreated ones. In control roots, 11 polypeptide bands with M.M. ranged from 193 to $25 \mathrm{KDa}$ were markedly 
isolated (Lane 6). In 6 h-chilled stressed roots, one HSP with M.M of $107 \mathrm{KDa}$ was appeared (Lane 7), while additional band with M.M of $52 \mathrm{KDa}$ was appeared during $6 \mathrm{~h}$ reacclimation period (Lane 8) (Table 6b). Four polypeptides with M.M. of $175,116,71$ and $65 \mathrm{KDa}$ were disappeared with appearance of $87 \mathrm{KDa}$ polypeptide HSPs after exposure of broad bean roots to low temperature for $24 \mathrm{~h}$ (Lane 9). At $6 \mathrm{~h}$ reacclimation period, polypeptide bands with M.M. 116, 92, 71 and 56 KDa were markedly recorded (Lane 10).

TABLE 6a. Survey of leave protein bands among chilling stress and reacclimation (6 h Reac) period of 15 day- old broad bean seedlings.

\begin{tabular}{|c|c|c|c|c|c|}
\hline $\begin{array}{l}\text { Band M.M. } \\
\text { KDa }\end{array}$ & $\begin{array}{c}1 \\
\text { cont. }\end{array}$ & $\begin{array}{c}2 \\
6 \mathrm{~h} \text { chilled }\end{array}$ & $\begin{array}{c}3 \\
\text { 6h Reac }\end{array}$ & $\begin{array}{c}4 \\
\text { 24h chilled }\end{array}$ & $\begin{array}{c}5 \\
\text { 6h Reac }\end{array}$ \\
\hline 214 & + & + & + & + & + \\
\hline 210 & + & + & + & + & + \\
\hline 190 & - & - & - & - & - \\
\hline 185 & + & + & + & + & + \\
\hline 180 & + & + & + & + & + \\
\hline 175 & - & - & - & + & - \\
\hline 165 & + & + & + & + & + \\
\hline 160 & + & + & + & + & + \\
\hline 156 & + & + & + & - & + \\
\hline 153 & + & + & + & + & + \\
\hline 140 & - & - & - & - & - \\
\hline 127 & + & + & + & - & + \\
\hline 109 & - & - & - & - & - \\
\hline 104 & + & - & - & - & - \\
\hline 102 & - & - & - & - & - \\
\hline 95 & - & - & - & + & - \\
\hline 85 & - & - & - & - & - \\
\hline 84 & + & + & + & - & + \\
\hline 76 & - & - & - & - & - \\
\hline 75 & - & + & + & - & - \\
\hline 71 & + & - & - & - & - \\
\hline 69 & - & + & + & - & - \\
\hline 58 & - & - & - & + & - \\
\hline 47 & + & + & + & + & + \\
\hline 35 & - & - & - & - & - \\
\hline 30 & - & - & - & + & - \\
\hline 25 & + & + & + & + & + \\
\hline
\end{tabular}


TABLE 6b. Survey of root protein bands among chilling stress and reacclimation (6h reac) period of 15 day- old broad bean seedlings.

\begin{tabular}{|c|c|c|c|c|c|}
\hline $\begin{array}{l}\text { Band M.M. } \\
\text { KDa }\end{array}$ & 6 & 7 & 8 & 9 & 10 \\
\hline 193 & + & + & + & + & + \\
\hline 175 & + & + & - & - & - \\
\hline 151 & + & + & + & + & + \\
\hline 140 & + & + & + & + & + \\
\hline 127 & - & - & - & - & - \\
\hline 116 & + & + & + & - & + \\
\hline 107 & - & + & + & - & - \\
\hline 106 & - & - & - & - & - \\
\hline 100 & + & + & + & + & + \\
\hline 95 & - & - & - & - & - \\
\hline 92 & - & - & - & - & + \\
\hline 87 & - & - & - & + & - \\
\hline 84 & - & - & - & - & - \\
\hline 71 & + & + & + & - & + \\
\hline 65 & + & + & + & - & + \\
\hline 60 & + & + & + & + & + \\
\hline 56 & - & - & - & - & + \\
\hline 52 & - & - & + & - & - \\
\hline 30 & + & + & + & + & + \\
\hline 25 & + & + & + & + & + \\
\hline
\end{tabular}

\section{Discussion}

Exposure of broad bean plants to non-lethal low temperature resulted in a significant decrease in normalized content of macronutrients $(\mathrm{K}, \mathrm{Ca}$, $\mathrm{Mg}, \mathrm{P}$ and $\mathrm{Fe}$ ) and $\mathrm{N}\left(\right.$ as $\mathrm{NO}_{3}^{-}$) in the leaves and roots, reflecting a decline of nutrient uptake. This decline was accompanied with an increase of $\mathrm{Cu}$ and $\mathrm{Zn}$ contents. In addition, there was a significant increase in electrolyte leakage (E.L.\%) of broad bean leaves with increasing the duration of chilling stress revealing the disturbance of plasma membrane integrity and that might be attributed to generation of ROS. Taspinar et al. (2009) and Nxawe et al. (2010) stated that low temperature resulted in a marked reduction of $\mathrm{K}, \mathrm{Ca}, \mathrm{Fe}$ and $\mathrm{P}$ in different organs of several plants, while, Jan et al. (2015) concluded that no significant variation in $\mathrm{N}, \mathrm{K}$ and $\mathrm{Ca}$ content in rice plants grown under different low temperatures, revealing that short low temperature shock did not affect the ions balance. In agreement with this view, short period of exposure to chilling temperature $(6 \mathrm{~h})$ had an insignificant effect on the concentration of nutrient ions content in leaves and roots of broad bean plants. Thus, the decrease of normalized concentrations of nutrient ions and $\mathrm{NO}_{3}^{-}$contents of long period chilling-stressed broad bean leaves and roots might be attributed to decrease of water absorption and hence nutrient uptake as well as allocation within the plant organs. These results could suggest that an increase in water viscosity of hydroponic solution (Wan et al., 2001) and decline of respiration rate (Rinaldelli \& Bandinelli, 1999) resulted in a marked decrease of passive and active absorption 
processes. Moreover, increasing the dehydration of roots by decreasing root temperature (Shabala \& Shabala, 2002) and disturbance of plasma membranes potential (Lukatkin et al., 2012) might enhance the EL\% (Table 1) and imbalance of nutrient absorption. Also, the significant increase of $\mathrm{Cu}$ and $\mathrm{Zn}$ ion contents, which accompanied with an increase of $\mathrm{H}_{2} \mathrm{O}_{2}$ and MDA contents and electrolyte leakage, might reveal the damage and disturbance of plasma membranes and, therefore, suppression of nutrient uptake and accumulation. Close et al. (2003) suggested that low N nutritional status and increase of $\mathrm{Cu}$ and $\mathrm{Zn}$ in plants grown under low temperature resulted in an increase in photooxidation and generation of ROS which induced cell membrane damage in plants.

Mostafa \& Sorour (2014) reported that plants exposed to non-lethal temperature, have the ability to withstand and acclimate to heat stress via prevention of heat damage and repair of heat-sensitive components. In accordance with these views transferring chill-stressed broad bean plants to natural environmental conditions for 6 $\mathrm{h}$ (reacclimation period) resulted in a significant increase of $\mathrm{K}, \mathrm{Ca}, \mathrm{Mg}, \mathrm{P}$ ions and decrease in $\mathrm{NO}_{3}^{-}$ accumulation in roots, as well as a significant decline of $\mathrm{H}_{2} \mathrm{O}_{2}$ and MDA contents. These results might indicate that an alleviate defense mechanisms for repairing the heat sensitive components and improving the plasma membranes integrity which return the ability for absorb water and nutrients as well as increase the transportation within the plants. In this study, several HSP bands were markedly appeared during chilling stress and recovery period, and that might reflect their role for repairing specific growth promoted proteins. Xin \& Browse (2000) proposed that the maintenance of lipid composition of the plasma membranes and presence of cytoprotectants, such as sugars, phenolics, quaternary ammonium compounds and polyamines, could increase the dehydration tolerance. In addition, Saruyama et al. (2004) reported that maintenance of membrane integrity at low temperature has been considered as an important factor in the resistance to low temperature.

It has been known that increasing the activity of enzymatic antioxidants might reflect the suppression of ROS generation (Kang \& Saltveit, 2002 and Cui \& Zhou, 2013). In this study, there was a significant increase of SOD activity in leaves and roots with increasing the duration of exposure of broad bean plants to non-lethal low temperature indicating the principle role of SOD in the dismutating the released toxic superoxide radicals to $\mathrm{H}_{2} \mathrm{O}_{2}$. Similarly, Mohammadian et al. (2012) reported that SOD activity in flavedo tissues of ripened three cultivars of citrus plants was significantly increased under low temperature treatments. On the other hand, Ping et al. (2012) showed that a significant decrease of SOD in the rubber roots clones under chilling stress. In accordance with this observation, during $6 \mathrm{~h}$ reacclimation period SOD activity in leaves and roots of chilled-stressed broad bean plants was significantly decreased, compared to stressed ones, and that might be pointed to generation of other defense mechanisms. Conversely to these results, Karpinski et al. (1994) showed an increase of SOD activity in Pinus sylvestris plant during the recovery period from winter stress.

During this study, CAT and APx activities in leaves and roots of broad bean plants were significantly increased in response to increase the duration of chilling exposure. In this connection, many authors have been reported that low temperature stimulated the scavenging of $\mathrm{H}_{2} \mathrm{O}_{2}$ by both enzymatic antioxidants CAT and APx (Hajiboland \& Habibi, 2011; Mohammadian et al., 2012; Cui et al., 2013 and Mostafa \& Sorour, 2014). In contrast, Kang \& Saltveit (2001) and Ping et al. (2012) have reported that chilling stress resulted in a significant decrease of CAT activity in cucumber seedlings and rubber colenes respectively, while, Galli et al. (2009) showed that APx activity did not show a clear trend during the cold storage of pawpaw fruits. It is noteworthy that during the post-chilling period (6 $\mathrm{h}$ reacclimation), there was a significant increase of CAT and APx activities in contrast to SOD, and that was accompanied with a significant decrease of $\mathrm{H}_{2} \mathrm{O}_{2}$ and MDA contents as well as electrolyte leakage with a marked increase of macronutrient contents. These observations might indicate the cold stability of CAT and APx and their roles as an acclimative mechanism to improve the plasma membranes from chilling injury. Similarly, Kang \& Saltveit (2001) showed a marked increase of CAT in the chilled high-vigour cucumber radicals compared to lower-vigour radicals, and they suggested that chilling-tolerant cucumber cultivar able to increase the CAT activity during the recovery period after chilling stress.

Under prevailing experimental conditions, glutathione reductase (GR) activity was significantly enhanced during the duration 
of chilling stress. Moreover, in this study, the significant increase of both APx and GR activities during the $6 \mathrm{~h}$ reacclimation period were accompanied with a significant decline of $\mathrm{H}_{2} \mathrm{O}_{2}$ and MDA contents. These results might be explained by an enhancement of ascorbateglutathione cycle to impair $\mathrm{H}_{2} \mathrm{O}_{2}$ accumulation and, therefore, decrease the oxidative damage of plasma membranes.

Polyphenol oxidase (PPO) activity was significantly increased with increasing duration of chilling stress and reacclimation periods. Similarly, Maldonado et al. (2002) and Nguyen et al. (2003) have been showed an increase of PPO activity in Annona cherimola and banana plants, respectively grown under low temperature conditions. In contrast, Wongsheree et al. (2009) reported that, in mature and young lemon leaves, PPO activity was markedly decreased at $4^{\circ} \mathrm{C}$ and that associated with a decline of phenolic levels. Thus, the increase of PPO activity in leaves and roots of broad bean during chilling stress and reacclimation periods might reveal the role of PPO in scavenging the generated oxygen radicals using phenolics as reductants as well as removing the toxic effect of accumulated phenolics. Close \& McArthur (2002) reported that phenolics can donate hydrogen from $\mathrm{OH}^{-}$group to reduce or scavenge produced free oxygen radicals, While Weisany et al. (2012) concluded that the increase of PPO activity was associated with remove the toxic effect of accumulated phenolics in tissues.

Badowiec et al. (2013) reported that regulation of gene expression and, hence, protein pattern or expression of HSPs may help to develop a strategy mechanism in response to various environmental stresses. In this study, exposure of broad bean plants to non-lethal low temperature resulted in a marked variation in band position and intensity during the duration of exposure and reacclimation period. These observations might reflect the induction of specific stress or/and protective proteins involve in increasing cold acclimation or avoidance and detoxification of generated growth and metabolic inhibitors such as ROS (Shinozaki et al., 2003). Therefore, it can been suggested that exposure of broad bean plants to chilling temperature and $6 \mathrm{~h}$ reacclimation periods, in this study, could result in an induction of several genes expression for specific proteins biosynthesis, differing in position and intensity, implicating in suppression of the inhibitory effects of generated ROS on plasma membrane integrity and metabolic processes.
In conclusion, chilling temperature might inhibit mineral nutrients uptake and their allocation within the plants. This inhibition could be explained by the effect of low temperature on the nature of hydroponic solution, chemical reaction rate of nutrients in the solution, disturbance of plasma membrane integrity and the physiological and biochemical reactions and/or all the above aspects. These inhibitory effects were associated with a significant increase of antioxidant enzyme activities (SOD, CAT, APx, GR and PPO) and decrease of $\mathrm{H}_{2} \mathrm{O}_{2}$ and MDA contents as well as electrolyte leakage. Moreover, the expression of various HSPs might improve plasma membrane integrity from the inhibitory effect of generated ROS during chilling stress and reacclimation periods.

\section{References}

Asada, K. (1999) The water-water cycle in chloroplasts: Scavenging of active oxygen and dissipation of excess photons. Annu. Rev. Plant physiol. Plant Mol. Biol. 50, 601-639.

AzevedoNeto, A.D.D., Prisco, J.T., Eneas-Filho, J., De Abreu, C.E.B. and Gomes-Filho, E. (2006) Effect of salt stress on antioxidantive enzymes and lipid peroxidation in leaves and roots of salt-tolerant and salt-sensitive maize genotypes. Environ. Exp. Bot. 56, 87-94.

Badowiec, A., Swigonska, S. and Weidner, S. (2013) Changes in the protein patterns in pea Pisum sativum L. roots under the influence of long-and shortterm chilling stress and post-stress recovery. Plant Physiol. Biochem. 71, 315-324.

Close, D.C. and McArthur, C. (2002) Rethinking the role of many plant phenolics-protection against photodamage not herbivores.Oikos, 99, 166-172.

Close, D.C., Beadle, C.L. and Hovenden, M.J. (2003) Interactive effects of nitrogen and irradiance on sustained xanthophyll cycle engagement in Eucalyptus nitensleaves during winter. Oecologia, 134, 32-36.

Cui, C. and Zhou, Q.Y. (2013) Antioxidant enzyme and morphological characteristics of roots of three Nicotiana tabacum L. genotype seedlings under chilling stress. Afric. J. Agric. 8, 64-69.

Cui, C., Zhou, Q.Y., Zhang, C.B., Wang, L.J. and Tan, Z.F.(2013) Effect of chilling stress on membrane lipid peroxidation and antioxidant system of Nicotiana tabacum L. Seedling. Afric. J. Agric. 8, 6079-6085. 
Dionisio-Sese, M. and Tobita, S. (1998) Antioxidant responses of rice seedlings to salinity stress. Plant Sci. 135, 1-9.

Edwards, E., Rawsthorne, S. and Mullineaux, P. (1991) Subcellular distribution of multiple forms of glutathione reductase in leaves of pea Pisum sativum L. Planta, 180, 278-284.

El-Mahtasem, M.O. (2008) Nitrate uptake and assimilation efficiency of excised leaves of barley (C3) and maize (C4) plants. I) Effect of temperature on nitrate uptake and assimilation. International Meeting on Soil Fertility Land Management and Agroclimatology. Turkey. pp.1199-509.

Ercoli, L., Mariotti, M., Masoni, A. and Arduini, I. (2004) Growth responses of sorghum plants to chilling temperature and duration of exposure. Eur. J. Agr. 21, 93-103.

Foyer, C.H. and Halliwell, B. (1976) The presence of glutathione and glutathione reductase in chloroplasts: a proposed role in ascorbic acid metabolism. Planta, 133, 21-25.

Galli, F., Archold, D.D. and Pomper, K.W.(2009) Pawpaw fruit chilling injury and antioxidant protection. J. Amer. Sec. Hart. Sci. 134, 466-471.

Giannopolitis, C.N. and Ries, S.K. (1977) Superoxide dismutase. Occurrence in higher plants. Plant Physiol. 59, 309-314.

Gill, S.S. and Tuteja, N. (2010) Reactive oxygen species and antioxidant machinery in abiotic stress tolerance in crop plants. Plant Physiol. Biochem. 118, 909-930.

Hajiboland, R. and Habibi, G. (2011) Contrastive response of spring and winter wheat cultivars to chilling and acclimation treatments. Acta Agric. Solven, 97,233-239.

Jan, M., Shinwari, K.I., Shah, G., Khan, M.H., Ullah, S., Hameed, A. and Malook, I. (2015) Consequences of short term low temperature stress on physiological and biochemical aspects of rice Oryza sativa L. Sci. Agri. 10, 1-14.

Johnson, C.M. and Ulrich, V. (1950) Determination of nitrate in plant material. Analy. Chem. 22, 15261529.

Kang, H.M. and Saltveit, M.E. (2001) Enzymatic antioxidant defense systems in chilled and heat shocked cucumber seedlings radicals. Physiol. Planta, 113, 548-556.

Kang, H.M. and Saltveit, M.E. (2002) Effect of chilling on antioxidant enzymes and DPPH-radical scavenging activity of high-and low-vigour cucumber seedling radicals. Plant Cell Environ. 25, 1233-1238.

Karpinski, S., Karpinska, B., Wingsle, G. and Hallgren, J.E. (1994) Molecular responses to photooxidative stress in Pinus sylvestris. I, Differential expression of nuclear and plastid genes in relation to recovery from winter stress. Physiol. Plant, 90,358-366.

Kumar, K.B. and Khan, P.A. (1982) Peroxidase and polyphenol oxidase in excised ragi Eleusine coracana cv. PR 202 leaves during senescence. Indian Journal of Experimental Botany, 20, 412-416.

Laemmli, U.K. (1970) Cleavage of structureal proteins during the assembly of the heat of bacteriophage T4. Nature, 227, 680-685.

Lukatkin, A.S., Brazaityte, A., Bobinas, C. and Duchovskis, P. (2012) Chilling injury in chillingsensitive plants. Agric. 99, 111-124.

Maldonado, R., Molina-Garica, A.D., Sanchez-Ballestya, M.T., Escribano, M.J. and Merodio, C. (2002) High $\mathrm{CO}_{2}$ atmosphere modulating the phenolic response associated with cell adhesion and hardening of Annona cherimolafruit stored at chilling temperature. J. Agr. Food Chem. 50,7564-7569.

Mckersie B.D. and Leshem, Y.Y. (1994) Stress and stress coping in cultivated plants. Biol. Plant. 37, 256-261.

Mohammadian, M.A., Largani, Z.K. and Sajedi, R.H. (2012) Quantitative and qualitative comparison of antioxidant activity in the flavedo tissue of three cultivars of citrus fruit under cold stress. Aust. J. Crop Sci. 6, 402-406.

Mostafa, E.M. and Hassan, A.M.A. (2006) Effect of chilling on growth and nitrogen assimilation in Azolla caroliniana. Biol. Plant, 50, 166-170.

Mostafa, E.M. and Sorour,A.A. (2014) Role of nonenzymatic antioxidants in maize leaves Zea mays $\mathrm{L}$. exposed to heat stress. Egypt. J. Exp. Biol. (Bot). 11, 97-106.

Nakano, Y. and Asada, K. (1981) Hydrogen peroxide is scavenged by ascorbate specific peroxidases in spinach chloroplasts. Plant Cell Physiol. 22, 867-880.

Nguyen, T.B.T., Ketsa, S. and Van Doorn, W.G. (2003) Relationship between browning and the activities of polyphenol oxidase and phenylalanine ammonia lyase in banana peel during low temperature storage. Postharvest Biol. Technol. 30, 187-193.

Nxawe, S., Ndakidemi, P.A. and Laubscher, C.P. (2010) 
Possible effects of regulation hydroponic water temperature on plant growth, accumulation of nutrients and other metabolites. Africa. J. Biotec. 9, 9128-9134.

Ping, L., Jun-Jun, H., Yan-Li, Y., Xiao-Hong, D., RuXiong, C. and Li-Feng, W. (2012) Differential responses of two rubber tree clones to chilling stress. Afric. J. Biotec. 11, 13466-13471.

Rinaldellie, E. and Bandinelli, R. (1999) Proton extrusion in leaves of Olea europaea L. c.v frantoio and evidence for an ATP-driven H+ pump. A study carried out under different chemical, physical and electrophysiological conditions. Adv Hort Sci. 13, 113-124.

Saruyama, H., Onodera, H. and Uemura, M. (2004) Transgenic rice plants expressing wheat catalase show improved tolerance for chilling-induced damage in membranes. In: Rice is life: Scientific perspectives in the $21^{\text {st }}$ Century, Toriyama, K., Heong, K.L., Hardy, B. (Ed.). Proceedings of the World Rice Research Conference, Tsukuba, Japan, November 4-7.

Shabala, S. and Shabala, L. (2002) Kinetics of net $\mathrm{H}^{+}, \mathrm{Ca}^{+2}, \mathrm{~K}^{+}, \mathrm{Na}^{+}, \mathrm{NH}^{+4}$ and $\mathrm{Cl}$ fluxes associated with post-chilling recovery of plasma membrane transporters in Zea mays leaf and root tissues. Physiol. Plant, 114, 47-56.

Shinozaki, K., Shinozaki, Y.K. and Seki, M. (2003) Regulatory network of gene expression in the drought and cold stress responses. Plant Biol. 6, 410-417.

Suzuki, N. and Mittler, R. (2006) Reactive oxygen species and temperature stresses: A delicate balance between signaling and destruction. Physiol. Plant, 126, 45-51.

Taspinar, M.S., Dumlupinar, R., Demir, F., Cakmak, T. and Gulen, Y. (2009) Determination of chilling temperature effects on nutrient elements composition and distribution in cole Brassica oleracea L.CU. Acephala using the WDXRF spectroscopic technique. Afric. J. Biotech. 8, 6569-6575.

Velikova, V., Yordanov, I. and Edreva, A. (2000) Oxidative stress and some antioxidant system in acid rain treated bean plant: protective role of exogenous polyamines. Plant Sci. 115,59-66.

Vierling, E. (1991) The role of heat shock proteins in plants. Annu. Rev. Plant Physiol. Plant Mol. Biol. 42, 579-620.

Wan, X., Zwiazek, J.J., Lieffers, V.J. and Landhausser, S.M. (2001) Hydraulic conductance in aspen Populus tremuloides seedling exposed to low root temperature. Tree Physiol. 21, 691-696.

Weisany, W., Sohrabi, Y., Heidari, G., Siosemardeh, A. and Ghassemi-Golezani, K. (2012) Changes in antioxidant enzymes activity and plant performance by salinity stress and zinc application in soybean Glycine max L. Plant Omics. J. 5, 60-67.

Wongsheree, T., Kestsa, S. and Doorn, W.D.V. (2009) The relationship between chilling injury and membrane damage in lemon basil Ocimum X Citriodourum leaves. Postharvest Biol. Technol. 51, 91-96.

Xin, Z. and Browse, J. (2000) Cold comfort farm: The acclimation of plants to freezing temperature. Plant Cell Environ. 23, 893-902.

Yin, G., Sun, H., Xin, X., Qin, G., Liang, Z. and Jing, X. (2009) Mitochondria damage in the soybean seed axis during imbibition at chilling temperatures. Plant Cell Physiol. 50, 1305-1318.

Zhang, F., Wang, Y., Lou, Z. and Dong, J. (2007) Effect of heavy metal stress on antioxidative enzymes and lipid peroxidation in leaves and roots of two mangrove plant seedlings (Kandelia candel and Bruguiera gymnorrhiza). Chemosphere, 67, 44-50.

(Received 29/12/2016; accepted 28/ 8 /2017 ) 


\section{التغيرات فى مضادات الأكسده الانزيميه والأملاح المعدنيه فى نبات الفول استجابه لاجهاد الصقيع واعادة التأقلم}

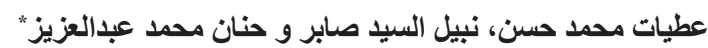

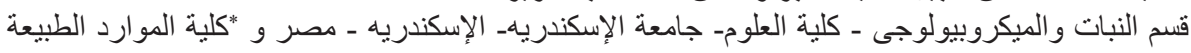
و العلوم البيئية- جامعة عمر المختار - ليبيا.

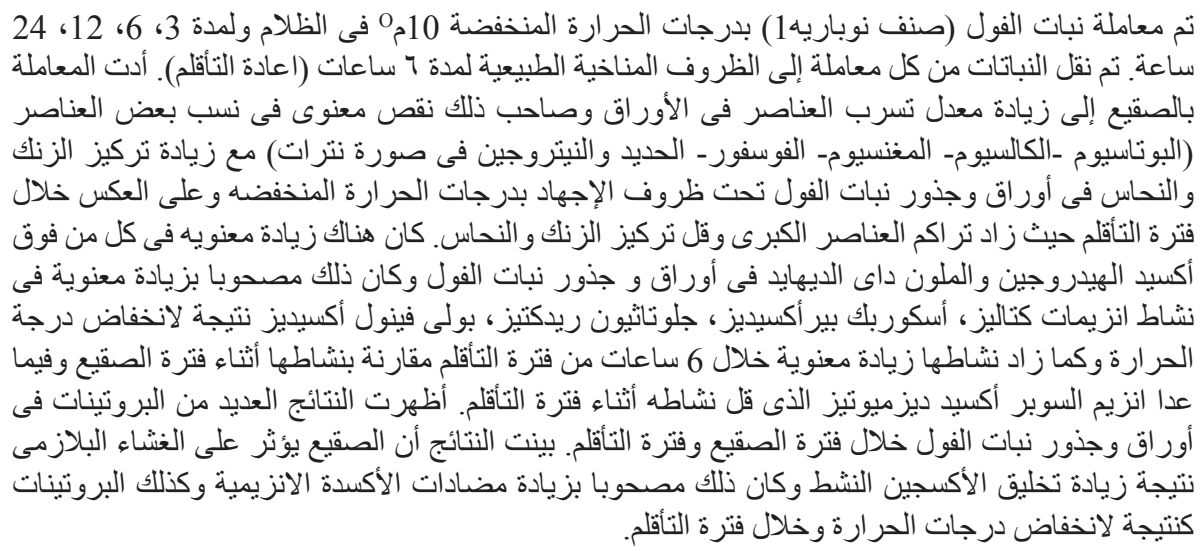

